\title{
Pre- and postjunctional inhibitory effects of fenspiride on guinea-pig bronchi
}

\author{
V. Girard*, E. Naline*, O. Crambes**, M. Malbezin**, R.E. Malmström+, \\ J.M. Lundberg+, C. Advenier*
}

Pre-and postjunctional inhibitory effects of fenspiride on guinea-pig bronchi. V. Girard, E. Naline, O. Crambes, M. Malbezin, R.E. Malmström, J.M. Lundberg, C. Advenier. (C)ERS Journals Ltd 1997.

ABSTRACT: Fenspiride is a drug with potential benefits in the treatment of obstructive airways disease. It has antibronchoconstriction and anti-inflammatory properties. The aim of this study was to investigate the effect of this drug on the contractions induced in the guinea-pig isolated main bronchus and perfused lung by electrical field stimulation (EFS) or exogenously added agents.

Bronchi were stimulated transmurally in the presence of indomethacin $10^{-6} \mathrm{M}$ and propranolol $10^{-6} \mathrm{M}$, and isometric tension was measured. In the perfused lung model, calcitonin gene-related peptide (CGRP) release was determined in the perfusate fractions as a measure of neuropeptide production.

Two successive contractile responses were observed: a rapid cholinergic contraction, followed by a long-lasting contraction due to local release of neuropeptides from C-fibre endings. Fenspiride $\left(10^{-6}\right.$ to $\left.10^{-4} \mathrm{M}\right)$ inhibited the nonadrenergic, noncholinergic (NANC) component of the contraction of the guinea-pig isolated main bronchus induced by EFS. Fenspiride significantly affected contractions induced by exogenously added substance $P$ or [Nle10]-NKA(4-10) only at concentrations higher than $10^{-3} \mathrm{M}$. In the guinea-pig perfused lung, fenspiride inhibited low pH- but not capsaicin-evoked release of CGRP. At higher concentrations $\left(1^{-4}\right.$ $M$ to $3 \times 10^{-4} \mathrm{M}$ ) fenspiride exhibited a significant inhibitory effect both on the cholinergic component of contractile response induced by EFS in the guinea-pig isolated main bronchus and on exogenously added acetylcholine.

In conclusion, the result of this study suggests that fenspiride, in moderate concentrations, reduces the release of neuropeptides, including tachykinins, from sensory nerve endings at a prejunctional level. At higher concentrations, postjunctional actions on bronchial smooth muscle are also present.

Eur Respir J 1997; 10: 1015-1020.
*Faculté de Médecine Paris-Ouest, Université Paris V, Paris, France. **Institut de Recherche International Servier, Courbevoie, France. +Division of Pharmacology, Dept of Physiology and Pharmacology, Karolinska Institute, Stockholm, Sweden.

Correspondence: C. Advenier

Faculté de Médecine

15 rue l'Ecole de Médecine

F-75270 Paris Cedex 06

France

Keywords: Fenspiride guinea-pig

tachykinins

Received: January 111996

Accepted after revision January 281997
Several experimental studies have demonstrated that fenspiride is a drug that exerts antibronchoconstriction and anti-inflammatory properties. The anti-inflammatory properties have been demonstrated during experimentally-induced inflammation in animals [1]. This effect has been related to an anti-free radical effect and an inhibition of cyclo-oxygenase activity $[1,2]$. Antibronchoconstrictor activity has been demonstrated in vitro in isolated guinea-pig trachea, with reversal of constriction induced by a variety of factors, and in vivo by reversing the bronchoconstriction induced by several agents, including capsaicin and citric acid [1, 3, 4].

In the airways, bronchial $\mathrm{C}$-fibre stimulation causes the release of tachykinins, including substance P (SP), neurokinin A (NKA), and calcitonin gene-related peptide (CGRP) [5]. On the basis of studies of endogenously released or exogenously administered neuropeptides, it has been established that these peptides induce bronchoconstriction, hypersecretion of mucus, vasodilatation, microvascular leakage, release of inflammatory mediators, and inflammatory cell chemotaxis. These proinflammatory effects may play a role in the pathogenesis of asthma, thereby suggesting that control of the local release of neuropeptides might be effective in the management of this disease [6-9].

It has been demonstrated that isolated guinea-pig main bronchi respond to electrical field stimulation (EFS) in vitro with a fast, cholinergic nerve-mediated contraction, followed by a long-lasting contraction that is not inhibited by atropine. This bronchoconstrictor response has been termed the excitatory nonadrenergic noncholinergic (e-NANC) response and is evoked by stimulation of capsaicin-sensitive sensory nerves [10-13], resulting in subsequent neuropeptide release [14]. The aim of the present study was to investigate the effects of fenspiride on the action and the release of sensory neuropeptides induced by EFS in the isolated guineapig main bronchus. To determine whether fenspiride acts at a pre- or a postjunctional level, we have also studied the effects of this drug on release of calcitonin generelated peptide-like immunoreactivity (CGRP-LI) in the perfused guinea-pig lung, and on the contracting effects 
of substance $\mathrm{P},\left[\mathrm{Nle}^{10}\right]-\mathrm{NKA}(4-10)$, a specific agonist of tachykinin neurokinin-2 $\left(\mathrm{NK}_{2}\right)$ receptors, and acetylcholine added exogenously to the organ bath. Finally, we have investigated whether fenspiride inhibited the effects of capsaicin, a drug known to induce the release of neuropeptides from sensory nerves.

\section{Methods}

\section{Preparation of bronchial smooth muscle}

Guinea-pig main bronchial segments were obtained from tricoloured guinea-pigs of either sex (250-350 g) anaesthetized with urethane $\left(1.25 \mathrm{~g} \cdot \mathrm{kg}^{-1}, i . p\right.$. $)$, and were suspended under an initial force of $2.0 \mathrm{~g}$ in Kreb's solution at $37^{\circ} \mathrm{C}$ aerated with $95 \% \mathrm{O}_{2} / 5 \% \mathrm{CO}_{2}$. After $1 \mathrm{~h}$ of equilibration, resting force was $1.5-2.0 \mathrm{~g}$. Under these conditions, responses to agonists were reproducible over several hours. Tension was measured isometrically with UF-1 Strain Gauges (Pioden, Canterbury, UK) and amplifiers (EMKA, France). The composition of Krebs solution was (mM): $\mathrm{NaCl} 118.0, \mathrm{KCl} 5.4, \mathrm{CaCl}_{2} 2.5$, $\mathrm{KH}_{2} \mathrm{PO}_{4} 1.2, \mathrm{MgSO}_{4} 1.2, \mathrm{NaHCO}_{3} 25.0$, and glucose 11.7.

In all experiments, after $1 \mathrm{~h}$ of equilibration, guineapig segments were contracted to maximal tension with acetylcholine $1 \mathrm{mM}$ and maximally relaxed with theophylline $3 \mathrm{mM}$. They were then allowed to equilibrate for $60 \mathrm{~min}$, while they were washed with Krebs solution every $15 \mathrm{~min}$.

\section{Electrical field stimulation}

Each organ bath was fitted with two platinum plate electrodes $\left(1 \mathrm{~cm}^{2}\right)$ placed alongside the tissue $(10 \mathrm{~mm}$ apart) for transmural EFS (biphasic pulse duration $1 \mathrm{~ms}$, constant current of $320 \mathrm{~mA}$ for $10 \mathrm{~s}$ ).

In all experiments, propranolol $10^{-6} \mathrm{M}$ and indomethacin $10^{-6} \mathrm{M}$ were added to the buffer solution to avoid the influence of adrenergic nerve stimulation and the indirect effects of prostaglandins on neuronal responses, respectively.

After tension had returned to the baseline tone, the preparation was stimulated at $0.5,1,4,8,16$, and 32 $\mathrm{Hz}$ for $1 \mathrm{~ms}$, and $320 \mathrm{~mA}$ current for $10 \mathrm{~s}$ using a stimulator (EMKA, France), where the voltage output was adjusted to give a constant current of $320 \mathrm{~mA}$ and biphasic rectangular pulse of alternating polarity. This procedure was repeated at $60 \mathrm{~min}$ intervals. Control experiments showed that responses to EFS during the experimental period were reproducible (see Results). These stimulus parameters caused an optimal reproducible biphasic contraction, followed by a sustained contractile response, both abolished by tetrodotoxin. The first, fast component is inhibited by atropine and results from stimulation of cholinergic nerves. The late and prolonged second phase is nonadrenergic noncholinergic (NANC) in nature, and is abolished or strongly reduced by antagonists of tachykinin $\mathrm{NK}_{2}$-receptors, such as SR 48968 and MEN 10,207, and partially reduced by CP-96,345, an antagonist of neurokinin-1 $\left(\mathrm{NK}_{1}\right)$-receptors $[12,14,15]$. We have previously observed that atropine $10^{-6} \mathrm{M}$ did not modify the NANC response and, similarly, SR $48968\left(10^{-10}\right.$ to $\left.10^{-7} \mathrm{M}\right)$ did not modify the cholinergic response [15], suggesting that in these experimental conditions no interaction between cholinergic and NANC responses was involved. In each bronchial ring, following a first series (control) of transmural EFS of $1-32 \mathrm{~Hz}$, a second series was performed $60 \mathrm{~min}$ later with or without (vehicle) fenspiride $\left(10^{-6}\right.$ to $10^{-4}$ $\mathrm{M})$ added to the bath $15 \mathrm{~min}$ before transmural stimulation. The results are expressed as percentages of contraction induced by acetylcholine $(1 \mathrm{mM})$. Results of the second series were compared to the first series.

Cumulative concentration-response curves to acetylcholine, substance P, [Nle $\left.{ }^{10}\right]$ NKA(4-10) and capsaicin

The inhibitory effects of fenspiride $10^{-4}$ to $10^{-2} \mathrm{M}$ used as preventive treatment were also studied. After 15 min pretreatment with fenspiride, in separate tissues cumulative concentration-response curves to acetylcholine $(\mathrm{ACh})\left(10^{-8}\right.$ to $\left.10^{-3} \mathrm{M}\right)$, SP $\left(10^{-8}\right.$ to $\left.3 \times 10^{-6} \mathrm{M}\right)$, capsaicin $\left(10^{-8}\right.$ to $\left.10^{-5} \mathrm{M}\right)$ or [Nle $\left.{ }^{10}\right]-\mathrm{NKA}(4-10)\left(10^{-9}\right.$ to $10^{-6}$ $\mathrm{M})$ were obtained by addition of the compounds every 5-10 min until a plateau was reached.

Contractions were expressed as a percentage of the contraction induced by the ACh $\left(10^{-3} \mathrm{M}\right)$ initially added to the bath. The experiments with $\left[\mathrm{Nle}^{10}\right]-\mathrm{NKA}(4-10)$ and SP were performed in the presence of phosphoramidon $\left(10^{-5} \mathrm{M}\right)$ to inhibit their metabolism.

\section{Release of CGRP-LI from perfused guinea-pig lung}

The guinea-pigs were anaesthetized with sodium pentobarbital (Pentothal ${ }^{\circledR}, 40 \mathrm{mg} \cdot \mathrm{kg}^{-1}$ i.p.). After tracheotomy, a tracheal tube connected to a rodent-respirator was inserted into the trachea, and the lung was ventilated with ambient air at a rate of 70 breaths $\cdot \mathrm{min}^{-1}$, using a tidal volume of about $3 \mathrm{~mL}$ adjusted according to the size of the animal. Insufflation pressure was recorded as an indicator of bronchoconstriction. The right and left ventricles of the heart were cut open and a tube was introduced into the pulmonary artery and the left ventricle for infusion and collection of perfused solution, respectively. The lung was perfused at a flow rate of $8 \mathrm{~mL} \cdot \mathrm{min}^{-1}$, with KrebsRinger solution at $37^{\circ} \mathrm{C}$ and with the following composition (mM): $\mathrm{NaCl} 118, \mathrm{CaCl}_{2} 2.5, \mathrm{MgSO}_{4} 1.2, \mathrm{NaHCO}_{3}$ 24.9, $\mathrm{KH}_{2} \mathrm{PO}_{4} 1.2, \mathrm{KCl} 4.7$, glucose 5.6, and hydroxyethylpiperazine ethanesulphonic acid (HEPES) 12.6, aerated with $93.5 \% \mathrm{O}_{2}$ and $6.5 \% \mathrm{CO}_{2}$ to give a $\mathrm{pH}$ of 7.4 . The $\beta_{2}$-adrenoceptor agonist terbutaline $\left(10^{-7} \mathrm{M}\right)$ was added to all solutions in order to obtain a stable baseline and graded functional response. Preliminary experiments have shown that terbutaline $\left(10^{-7} \mathrm{M}\right)$ did not affect CGRP release. Drugs were added to the perfusion medium. After 15 min of equilibration; when stable contractile conditions had been obtained, the lung was exposed to low $\mathrm{pH}$ solution or capsaicin with or without drugs (fenspiride $10^{-7}$ to $10^{-5} \mathrm{M}$, UK14304 $10^{-6} \mathrm{M}$ or tetrodotoxin $3 \times 10^{-7} \mathrm{M}$, for $15 \mathrm{~min})$. The low $\mathrm{pH}$ buffer solution had the following composition (mM): $\mathrm{NaCl} 140, \mathrm{KCl} 0.7, \mathrm{CaCl}_{2} 2.5$, $\mathrm{MgSO}_{4} 1.5, \mathrm{Na}_{2} \mathrm{HPO}_{4} 0.8, \mathrm{KH}_{2} \mathrm{PO}_{4} 5.9$ and glucose 11 , and the $\mathrm{pH}$ was adjusted to 5.8 with $\mathrm{HCl}$.

Perfusate fractions ( $3 \mathrm{~min}$ ) were collected in a beaker placed on ice, desalted using SEP-PAK $\mathrm{C}_{18}$ cartridges, freeze-dried in a vacuum-centrifuge, and redissolved in appropriate buffer for determination of CGRP-LI by radioimmunoassay (RIA) $[14,16]$. Release of CGRP-LI 
was monitored, since it is co-released with tachykinins, but it is metabolically more stable.

\section{Drugs}

The substances used were: acetylcholine $\mathrm{HCl}(\mathrm{PCH}$, Paris); indomethacin (Merck); [Nle $\left.{ }^{10}\right]-\mathrm{NKA}(4-10)$, phosphoramidon, propranolol $\mathrm{HCl}$, substance $\mathrm{P}$, yohimbine $\mathrm{HCl}$, capsaicin, naloxone $\mathrm{HCl}$, tetrodotoxin (Sigma, St Louis, USA); theophylline sodium anisate (Bruneau, Paris, France); fenspiride (Institut de Recherches Servier, Suresnes, France); terbutaline (Bricanyl ${ }^{\circledR}$, Astra Draco, Sweden); UK14304 (Pfizer, UK). All drugs were dissolved in distilled water and then diluted in Krebs solution. Theophylline was used as manufactured solution.

\section{Statistical analysis of results}

Mean and SEM values were calculated for each experimental series. Statistical differences between mean values were determined using analysis of variance or Student's t-test. A p-value less than 0.05 was considered statistically significant.

\section{Results}

Influence of fenspiride on the contractions of the guineapig isolated main bronchus induced by EFS

Figures 1 and 2 show the effects of fenspiride $10^{-6}$ to $10^{-4} \mathrm{M}$ on the two components of the contraction induced in the guinea-pig isolated main bronchus by EFS. Figure 3 shows an original tracing of the effects of fenspiride $10^{-4} \mathrm{M}$ on the two components of the contraction induced by EFS.
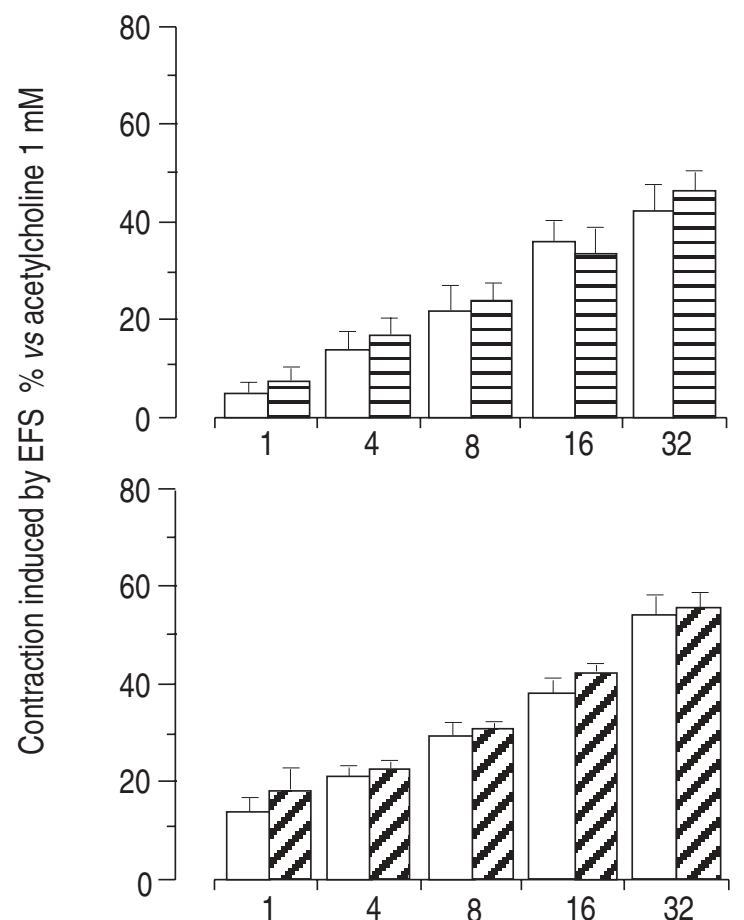

Fenspiride inhibited the first cholinergic component only at $10^{-4} \mathrm{M}$ (figs. 1 and 3 ). Conversely, this drug significantly inhibited the NANC component, even at $10^{-6} \mathrm{M}$. This inhibitory effect increased from $10^{-6}$ to $10^{-4}$ $M$ (figs. 2 and 3 ).

Influence of fenspiride on the concentration-response curves of ACh, SP, [Nle $\left.{ }^{10}\right]-N K A(4-10)$ and capsaicin

Figure 4 shows that fenspiride, at concentrations of $10^{-4}$ to $10^{-2} \mathrm{M}$, induced a shift to the right of the concentration response curves of ACh. Fenspiride $\left(10^{-3} \mathrm{M}\right)$ did not modify the effects of SP or [Nle $\left.{ }^{10}\right]-N K A(4-10)$. The effects of these contracting agents were significantly inhibited at higher fenspiride concentrations $\left(10^{-2}\right.$ and $3 \times 10^{-3} \mathrm{M}$, respectively); however, fenspiride $10^{-4} \mathrm{M}$ significantly inhibited the contraction caused by lower concentrations of capsaicin $\left(10^{-8}\right.$ and $\left.10^{-7} \mathrm{M}\right)$ but not by $10^{-6} \mathrm{M}$ capsaicin. For higher concentrations of fenspiride, the effect of capsaicin was more strongly inhibited (with fenspiride $10^{-3}$ and $3 \times 10^{-3} \mathrm{M}$ ) or completely abolished (fenspiride $10^{-2} \mathrm{M}$ ). This greater inhibitory effect of fenspiride $\left(3 \times 10^{-3}\right.$ and $\left.10^{-2} \mathrm{M}\right)$ occurs at concentrations that also inhibit contractions evoked by SP and $\left[\mathrm{Nle}^{10}\right]-\mathrm{NKA}(4-10)$.

\section{Influence of fenspiride on CGRP release}

A concentration of fenspiride $\left(10^{-5} \mathrm{M}\right)$, which had selective action on the NANC contraction, was found to markedly inhibit the CGRP release evoked by low $\mathrm{pH}(\mathrm{pH}$ 5.8 ) in the perfused guinea-pig lung (fig. 5a). Furthermore,
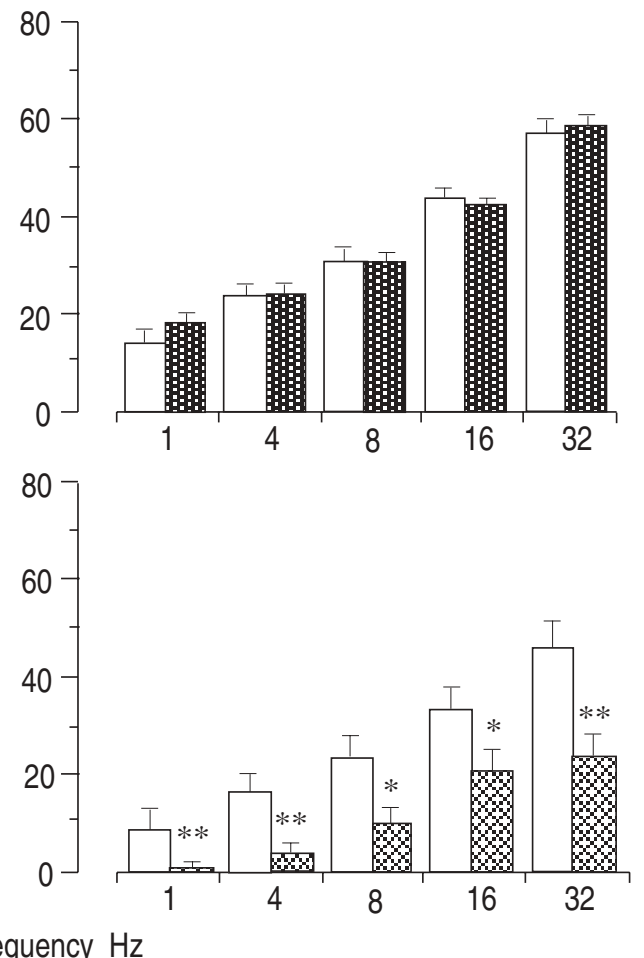

Fig. 1. - Histograms illustrating the effects of fenspiride $10^{-6}$ to $10^{-4} \mathrm{M}$ on the cholinergic response (first contraction) to electrical field stimulation (EFS) (1-32 Hz for $1 \mathrm{~ms}$; constant current of $320 \mathrm{~mA}$ for $10 \mathrm{~s}$ ) on the isolated guinea-pig main bronchus. Values are presented as mean \pm sEM for 6-7 animals. Columns represent contractions expressed as percentage of maximal contraction induced by acetylcholine $10^{-3} \mathrm{M}$. Experiments were performed in the presence of propranolol $\left(10^{-6} \mathrm{M}\right)$ and indomethacin $\left(10^{-6} \mathrm{M}\right) . \square$ : control (first series); $\square$ : control (second series);

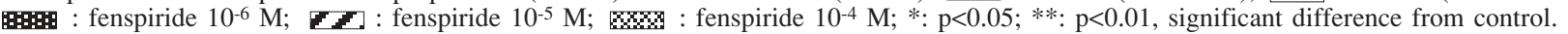




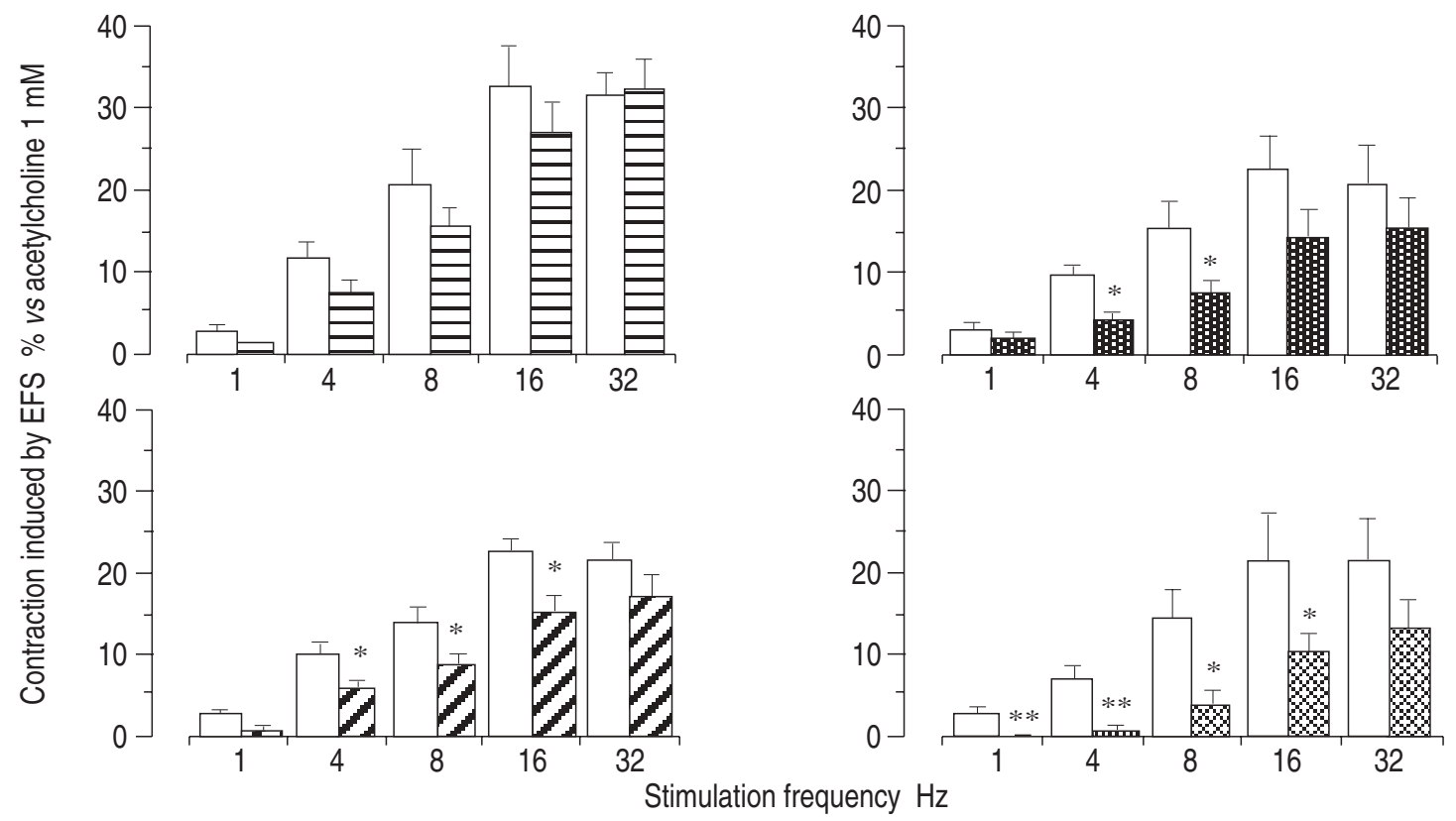

Fig. 2. - Histograms illustrating the effects of fenspiride $10^{-6}$ to $10^{-4} \mathrm{M}$ on the nonadrenergic noncholinergic (NANC) response (second contraction) to electrical field stimulation (EFS) $(1-32 \mathrm{~Hz}$ for $1 \mathrm{~ms}$; constant current of $320 \mathrm{~mA}$ for $10 \mathrm{~s}$ ) on the isolated guinea-pig main bronchus. Values are expressed as mean士SEM for 6-7 animals. Columns represent contractions expressed as percentage of maximal contraction induced by acetylcholine $10^{-3} \mathrm{M}$. Experiments were performed in the presence of propranolol $\left(10^{-6} \mathrm{M}\right)$ and indomethacin $\left(10^{-6} \mathrm{M}\right)$. $\square$ : control (first series);

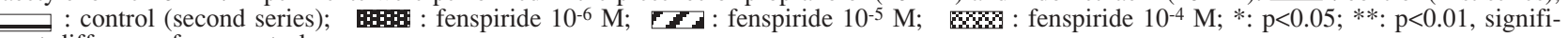
cant difference from control.

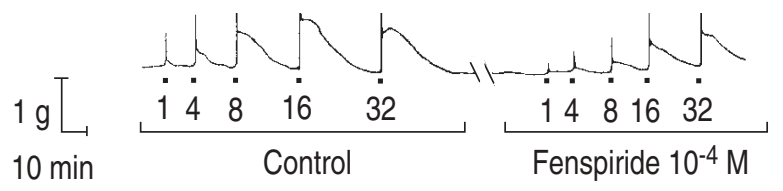

Fig. 3. - Representative traces of isometric tension showing the effects of fenspiride $10^{-4} \mathrm{M}$ on the cholinergic and nonadrenergic noncholinergic (NANC) responses to electrical field stimulation (EFS) $(1-32 \mathrm{~Hz}$ for $1 \mathrm{~ms}$; constant current of $320 \mathrm{~mA}$ for $10 \mathrm{~s}$ ) on the isolated guinea-pig main bronchus.

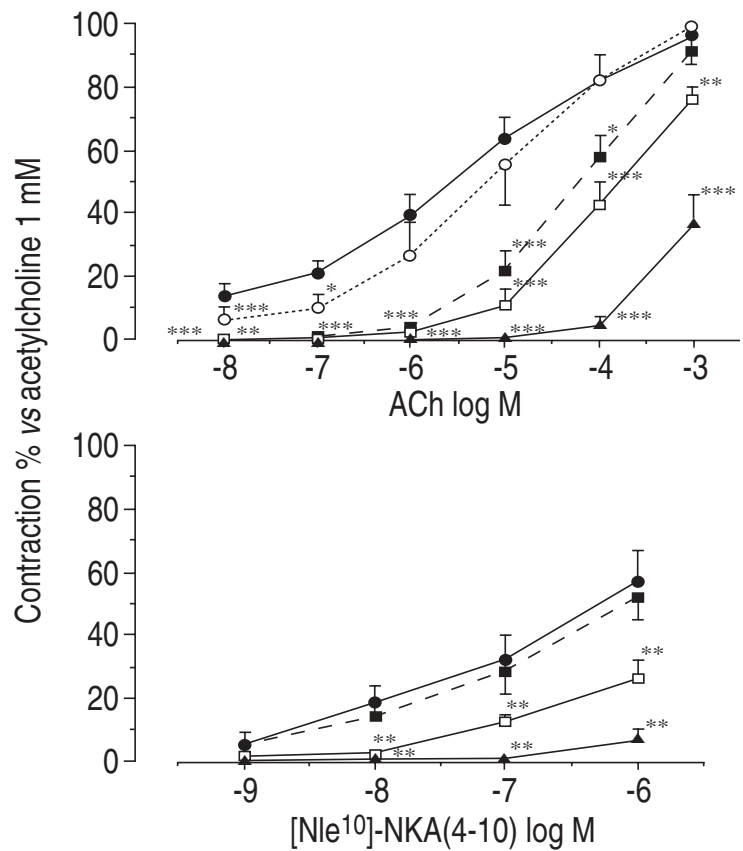

the $29 \pm 9 \%$ increase in insufflation pressure evoked by $\mathrm{pH} 5.8$ was significantly attenuated by fenspiride to $9 \pm 4 \%$ $(\mathrm{p}<0.05)$. The effects of fenspiride were mimicked by the $\alpha_{2}$-adrenoceptor agonist, UK14304 $\left(10^{-6} \mathrm{M}\right)$ and tetrodotoxin $\left(3 \times 10^{-7} \mathrm{M}\right)$ (fig. 5a). In contrast, the CGRP release (fig. $5 \mathrm{~b}$ ) and bronchoconstriction induced by capsaicin $\left(10^{-6} \mathrm{M}\right)$ were not influenced by fenspiride. Control CGRP-Li release evoked by capsaicin $(1 \mu \mathrm{M})$ or low $\mathrm{pH}$ $(\mathrm{pH} 5.8)$ were $0.9 \pm 0.1 \mathrm{pM}(\mathrm{n}=4)$ and $0.4 \pm 0.07 \mathrm{pM}(\mathrm{n}=4)$.
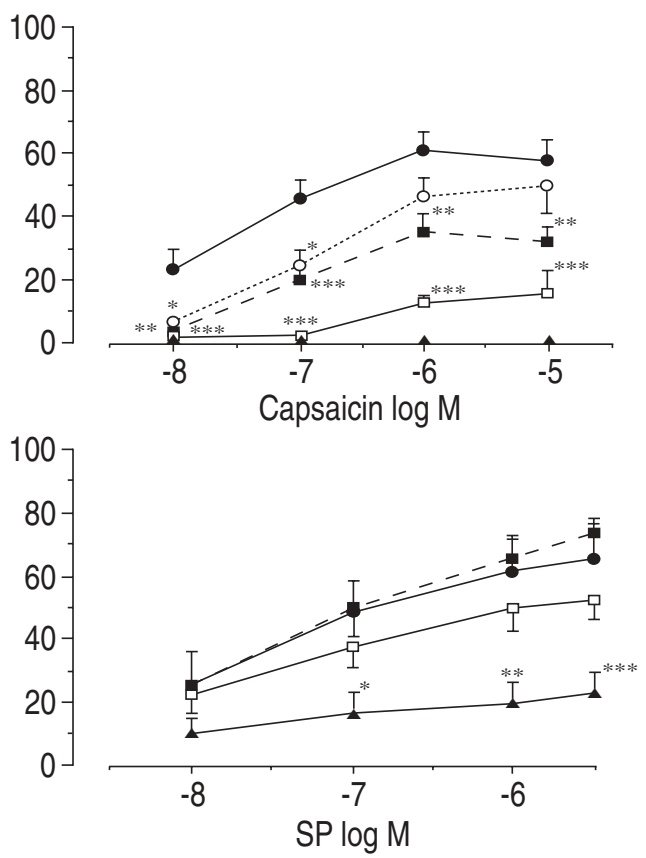

Fig. 4. - Influence of fenspiride $\left(10^{-4}\right.$ to $\left.10^{-2} \mathrm{M}\right)$ on the cumulative concentration-response curves of acetylcholine (ACh), substance $\mathrm{P}$ (SP), $\left[\mathrm{Nle}^{10}\right]-\mathrm{NKA}(4-10)$, and capsaicin on the isolated main bronchus of the guinea-pig. Values are presented as mean \pm SEM for 5-7 animals. $*$ : $\mathrm{p}<0.05$;

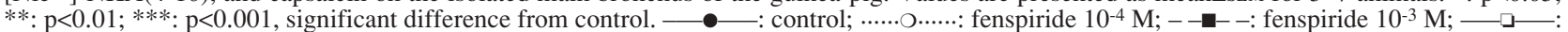
fenspiride $3 \times 10^{-3} \mathrm{M}$; - : fenspiride $10^{-2} \mathrm{M}$. 
a)

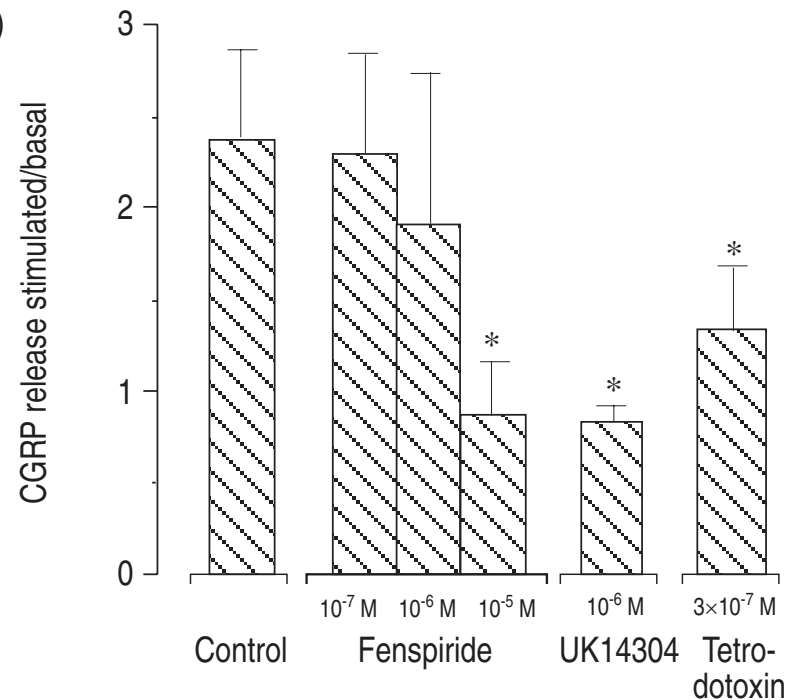

b)

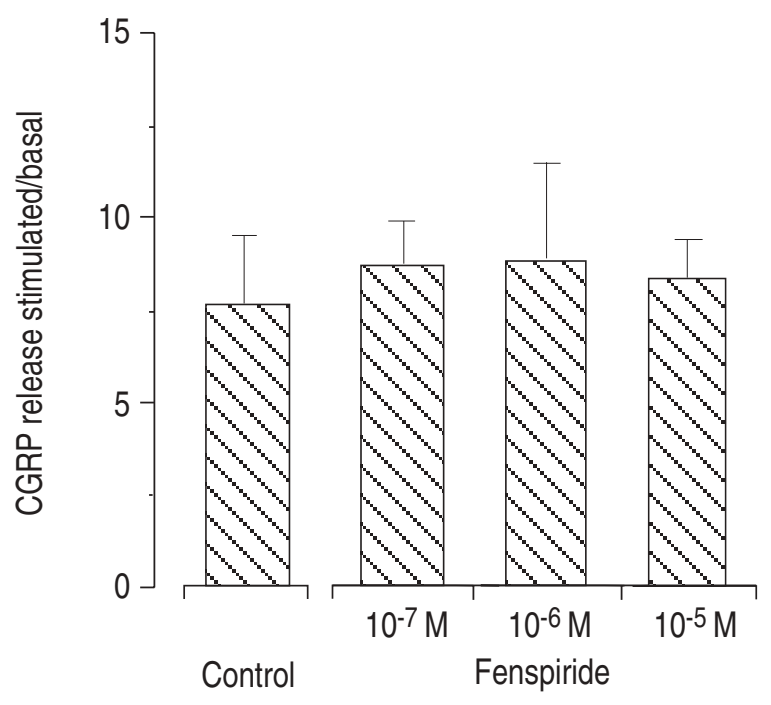

Fig. 5. - a) Influence of fenspiride $\left(10^{-7}\right.$ to $\left.10^{-5} \mathrm{M}\right)$, UK14304 $\left(10^{-6} \mathrm{M}\right)$ and tetrodotoxin $\left(3 \times 10^{-7} \mathrm{M}\right)$ on the CGRP release evoked by low $\mathrm{pH}$ (5.8) medium in perfused guinea-pig lung. b) Influence of fenspiride $\left(10^{-7}\right.$ to $\left.10^{-5} \mathrm{M}\right)$ on CGRP release upon capsaicin $(1 \mu \mathrm{M})$ infusion into perfused guinea-pig lung. Values are presented as mean $\pm \mathrm{sEM}, \mathrm{n}=4$ each. $*$ : $\mathrm{p}<0.05$, significant difference from control. CGRP: calcitonin gene-related peptide.

\section{Discussion}

Neuronal control of airways is complex. In addition to classic efferent cholinergic and adrenergic nerves, there are NANC sensory mechanisms, which are mediated by the release of neuropeptides. Neuronal responses may be measured in vitro using EFS with parameters that selectively activate nerves and not smooth muscle. EFS produced both a rapid cholinergic and a long-lasting noncholinergic contraction of bronchial smooth muscle of the guinea-pig due to release of sensory neuropeptides from C-fibre endings [10-13].

Our results demonstrate that fenspiride inhibits the two components of neurally-mediated biphasic response observed following EFS of the guinea-pig isolated main bronchus. There is, however, a difference between the inhibitory effects of fenspiride on these two components. The inhibition of the cholinergic response appears significant only for concentrations of $10^{-4} \mathrm{M}$ and higher, whereas the inhibition of the NANC component is significant even at $10^{-6} \mathrm{M}$ for the stimulation at 4 and 8 $\mathrm{Hz}$.

Furthermore, the mechanisms of the effects of fenspiride on these two components seem to be different. The results of the present study are consistent with a postjunctional inhibitory action of fenspiride on the cholinergic response, since we observed an inhibitory effect of this compound on cumulative concentrationresponse curves to $\mathrm{ACh}$ at $10^{-4} \mathrm{M}$ (fig. 3). In contrast, fenspiride appears to produce an inhibition of the NANC response predominantly at a prejunctional level, since fenspiride did not modify concentration-response curves to [Nle $\left.{ }^{10}\right]-\mathrm{NKA}(4-10)$, a specific agonist of tachykinin$\mathrm{NK}_{2}$ receptors, or to $\mathrm{SP}$ in concentrations lower than $3 \times 10^{-3} \mathrm{M}$. However, a postjunctional effect occurred at higher concentrations. Furthermore, the low pH-evoked CGRP release from the perfused lung $[17,18]$ was inhibited by fenspiride $10^{-5} \mathrm{M}$. Since the low $\mathrm{pH}$ response was inhibited by tetrodotoxin, it resembles the effects of EFS. The inhibition by fenspiride $\left(10^{-4} \mathrm{M}\right)$ of the effects of a low but not a high concentration of capsaicin, which induces a release of tachykinins from sensory nerve endings by different mechanisms, is in agreement with this hypothesis [16]. Thus, the failure of fenspiride to inhibit the contraction and CGRP release by a high concentration of capsaicin $\left(10^{-6} \mathrm{M}\right)$ is in agreement with the hypothesis that a high concentration of capsaicin causes peptide release via $\mathrm{Ca}^{2+}$ entry through receptor-gated channels, which may be less sensitive to prejunctional regulation [16].

Interestingly, in the present study, the effects of fenspiride on EFS are observed at concentrations lower than those reported for the antibronchoconstriction effect in the in vitro studies in guinea-pig trachea and human bronchus (-log concentration required to effect half the maximum response $(-\log E C 50)$ varying from 3.5 to 4 for various contractile agents) [1, 3], or for the antiinflammatory effect, such as the anti-free radical effect in guinea-pig alveolar macrophage (doses of the order of $\mathrm{mmol} \cdot \mathrm{L}^{-1}$ ) [2]. However, the clinical relevance of this effect remains difficult to specify, since the plasma levels of fenspiride observed during repeated administrations are close to $3 \times 10^{-6} \mathrm{M}$ (maximal concentration (Cmax): $800 \mathrm{ng} \cdot \mathrm{mL}^{-1}$ ) (unpublished data).

It has been shown by binding studies that this product has an affinity for the adrenergic $\left(\alpha_{1}\right)$ and histaminergic $\left(\mathrm{H}_{1}\right)$ receptors [1]. The binding to this type of receptor does not appear to be implicated in this inhibitory effect [19]. Studies are being carried out to determine another mechanism, notably an inhibitory effect of phosphodiesterase.

In conclusion, the present results show that fenspiride inhibits the cholinergic bronchoconstrictor response at high concentrations with a postjunctional mechanism, whereas fenspiride produces an inhibition of the nonadrenergic noncholinergic response at lower concentrations predominantly at a prejunctional level. Inhibition of the nonadrenergic noncholinergic system might be involved in the mechanism of action of fenspiride, but the clinical interest of this effect remains to be determined. 


\section{References}

1. Evrard Y, Kato G, Bodinier MC, Chapelain B. Fenspiride and inflammation in experimental pharmacology. Eur Respir Rev 1991; 1: 93-100.

2. Carre $\mathrm{Ph}$, Pipy B, Pinelli E, et al. In vitro effect of fenspiride on the production of free oxygen radicals, prostaglandins and leukotrienes by guinea-pig alveolar macrophages. Eur Respir Rev 1991; 1: 79-85.

3. Advenier C. Fenspiride and relaxation of tracheobronchial musculature: mechanism of action. Rhinology 1988; (Suppl. 4): 67-74.

4. Laude EA, Bee D, Crambes O, Howard P. Antitussive and bronchoconstriction actions of fenspiride in guineapigs. Eur Respir J 1995; 8: 1699-1704.

5. Lundberg JM, Brodin E, Saria A. Effects and distribution of vagal capsaicin-sensitive substance $\mathrm{P}$ neurons with special reference to the trachea and lungs. Acta Physiol Scand 1983; 119: 243-252.

6. Barnes PJ, Baraniuck JN, Belvisi MG. Neuropeptides in the respiratory tract. Am Rev Respir Dis 1991; 144 (Part I): 1187-1198 and (Part II) 1391-1399.

7. Frossard N, Advenier C. Tachykinin receptors and the airways. Life Sci 1991; 49: 1941-1953.

8. Joos GF, Germonpre PR, Kips JC, Peleman RA, Pauwels RA. Sensory neuropeptides and the human lower airways: present state and future directions. Eur Respir J 1994; 7: 1161-1171.

9. Maggi CA, Giachetti A, Dey RD, Said SI. Neuropeptides as regulators of airway function: vasoactive intestinal peptide and the tachykinins. Physiol Rev 1995; 75: 277-322.

10. Karlsson JA, Finney MJB, Persson CGA, Post C. Substance $\mathrm{P}$ antagonists and the role of tachykinins in the noncholinergic bronchoconstriction. Life Sci 1984; 35 : 2681-2691.
11. Lundberg JM, Saria A, Brodin E, et al. A substance P antagonist inhibits vagally-induced increase in vascular permeability and bronchial smooth muscle contraction of guinea-pig. Proc Natl Acad Sci USA 1983b; 80: 11201124.

12. Maggi CA, Patacchini R, Rovero P, Santiacioli P. Tachykinin receptor and noncholinergic bronchoconstriction in the guinea-pig isolated bronchi. Am Rev Respir Dis 1991; 144: 363-367.

13. Undem BJ, Myers AC, Barthlow H, Weinreich D. Vagal innervation of the guinea-pig bronchial smooth muscle. J Appl Physiol 1990; 69: 1336-1346.

14. Lou YP, Lee LY, Satoh H, Lundberg JM. Postjunctional inhibitory effect of the $\mathrm{NK}_{2}$ receptor antagonist, SR48968, on sensory NANC bronchoconstriction in the guinea-pig. Br J Pharmacol 1993; 109: 765-773.

15. Martin CAE, Naline E, Emonds-Alt X, Advenier C. Influence of ( \pm )-CP-96345 and SR 48968 on electrical field stimulation of the isolated guinea-pig main bronchus. Eur J Pharmacol 1992; 224: 137-143.

16. Lou YP, Franco-Cereceda A, Lundberg JM. Different ion channel mechanisms between low concentrations of capsaicin and high concentrations of capsaicin and nicotine regarding peptide release from pulmonary afferents. Acta Physiol Scand 1992; 146: 119-127.

17. Franco-Cereceda A, Lundberg JM. Capsazepine inhibits low $\mathrm{pH}$ - and lactic acid-evoked release of calcitonin gene-related peptide from sensory nerves in guinea-pig heart. Eur J Pharmacol 1992; 221: 183-184.

18. Auberson S, Lundberg JM. Lactic acid-induced plasma protein extravasation in rat airways by stimulation of nerves and $\mathrm{NK}_{1}$ receptor activation. Pharmacol Toxicol 1993; 73: 305-310.

19. Barnes PJ. Modulation of neurotransmission in airways. Physiol Rev 1992; 72: 699-729. 